and pedagogical discourse of coaching, a rather simplified model and a "narrowed" scheme of understanding the problem of the origin and formation of coaching has been established. Researchers emphasize the figure of the "founder" of modern coaching - California tennis coach, Harvard University professor W. Timothy Gallwey, who set out his cornerstone ideas in the book "The Inner Game of Tennis" and his several other bestsellers.

Based on the analysis of updated sources on this issue, it was concluded that the clearest and most fundamental influence on the development of the philosophy of coaching was made by four ideological teachings and systematic practices of the past and present. These are: Socratic methods of dialogue; humanistic direction of psychotherapy; D. Goleman's works in the field of emotional intelligence; methods of well-known sports coaches. Analyzed theories of well-known foreign scientists in a broad historical retrospective show how sports coaching, having accumulated millennial experience of Eastern and Western cultures in physical and spiritual improvement, has transformed itself into a modern phenomenon of coaching.

Key words: coaching, personality development, theories of origin, coaching, Socratic methods of dialogue, coach.

Дата надходженнястатті: 19.102021 p.

Рецензент: доктор педагогічних наук, доц̧ент Примакова В.В.

У, ДК 372.3.007

DOI https://doi.org/10.37915/pa.vi50.326

Султанова Н. В., orcid.org/0000-0003-3510-4662

\title{
ФОРМУВАННЯ ПРОФЕСІЙНОЇ КОМПЕТЕНТНОСТІ КЕРІВНИКА ЗАКЛАДУ ДОШКІЛЬНОЇ ОСВІТИ У СИСТЕМІ ПІСЯЯДИПЛОМНОЇ ОСВІТИ: IСТОРІЯ ТА СУЧАСНІСТЬ
}

У статті розкрито історико-педагогічні аспекти та сучасні організаційно-педагогічні засади процесу формування професійної компетентності керівників ЗДО в умовах установ післядипломної освіти, обьрунтовано можливості наступності дієвих механізмів та умов. Показано фактори впливу на підготовку та функційні обов'язки керівних кадрів у системі дошкільної освіти. Виявлено та представлено передумови розвитку освітніх установ та курсів для професійної підготовки педагогічних та керівних кадрів в Украӥні, у тому числі у галузі доикільної освіти.

Визначено актуальність формування професійної компетентності керівників закладів дошкільної освіти, яку ми трактуємо як динамічну комбінацію знань, умінь, навичок та інших особистісних $і$ ділових якостей, що визначають їхню здатність та гарантують готовність до професійного виконання керівних задач.

Розкрито основи управлінської культури керівників та зліст управлінської компетентності директорів дитячих садків. Проаналізовано Професійний стандарт Керівника закладу дошкільної освіти та виокремлено вимоги до його професійної діяльності у розрізі управлінських обов'язків та функцій. Наголошено, щзо формуванню професійної компетентності керівників закладів дошкільної освіти сприяе розвиток їхньої організаційної культури, у тому числі, у системі післядипломної освіти. Окреслено методологічне підррунтя професійного розвитку керівників ЗДО з позицій професійно-особистісного,

*(С) Султанова Н. В.

us 
Us ПЕДАГОГІЧНИЙ АЛЬМАНАХ. - 2021. - ВИПУСК 50

Us

професійно-компетентнісного становлення та професійної діяльності безпосередньо. Розкрито сутність організаційно-методологічних засад їхньої професійної підготовки, воснові якої лежить єдність компонентів: аксіологічно-мотиваційного, когнітивного та особистісного.

Акцентовано, що ядром професійної компетентності керівника закладу дошкільної освіти є кваліметрична складова, що відтворюе єдність теоретико-управлінської підготовленості та практичної здатності фахівців комплексно застосовувати прикладні анахітико-оціночні технологї̈ на керівних посадах.

Охарактеризовано мотиваційну складову та науково-методичний супровід курсів підвищення кваліфікації як системоутворюючих компонентів набуття професійної компетентності керівника закладу дошкільної освіти.

Зроблено висновки, що дотримання певних організаційно-методологічних засад професійної підготовки керівників ЗДО в умовах післядипломної освіти сприятиме якомога ефективнішому формуванню їхньої професійної компетентності.

Ключові слова: дошкільна освіта, історія педагогіки, заклади дошкільної освіти, керівник ЗДО, професійна компетентність, управлінська культура, організаційно-методологічні засадu.

Постановка проблеми. Реформування сучасної вітчизняної системи освіти сьогодні вимагає переосмислення метододогічних засад, провідної ідеї та стратегії підготовки керівних кадрів в галузі дошкільної освіти. Відсутність цілеспрямованої підготовки директорів освітніх установ та, зокрема, дошкільних закладів під час навчання у виші, актуалізуе проблему формування професійної компетентності керівників у системі післядипломної освіти та підвищення кваліфікації безпосередньо. Як наслідок, такі посади нерідко займають фахівці із різним рівнем освіти, знань та досвідом управдінської діядьності. До того ж, викдикає занепокоєння недостатня відповідність управлінського потенціалу керівників закладів дошкільної освіти, насамперед у сільській місцевості, вимогам професійного стандарту. Разом із тим, підвищення кваліфікації керівників 3ДО має забезпечуватися формами, дидактичними засобами й моделями навчання, що умождивлюють формування їхньої професійної компетентності на якісно новому рівні підготовки. Це дозволить їм перетворити ЗДО у світлі реформаційних та соціальних змін в українському суспільстві на сучасну інноваційну й відкриту освітню установу з позитивним корпоративним іміджем. Отже оптимізація процесу підвищення професійної компетентності керівників закладів дошкільної освіти передбачає пошук та апробування нового змісту навчальних курсів. Проте його оновленню сприятиме, на наш погляд, виокремлення та упровадження позитивних надбань з досвіду минулого століття.

Означена проблема не знайшла свого теоретичного обгрунтування та практичного розв'язання в умовах закладів післядипломної освіти. Це актуалізувало необхідність дослідження проблеми формування професійної компетентності керівників закладів дошкільної освіти у процесі післядипломного навчання, зокрема у розрізірізних історичних епох та, відповідно, освітніх модедей.

Аналіз досліджень. Науково-теоретичні засади розвитку неперервної педагогічної освіти висвітлено й обгрунтовано у працях І. Зязюна, В. Кременя, В. Аугового та ін. Проблеми розвитку дошкільної освіти порушено у працях вітчизняних вчених (Г. Беленька, М. Євтух, Т. Слободянюк, М. Стельмахович, О. Сухомлинська та ін.). Аналіз теоретичних засад проблеми дослідження констатує значний інтерес науковців до проблеми підготовки педагогічних та керівних кадрів освітніх установ (В. Бобир, В. Семиченко, Т. Сорочан), зокрема у галузі дошкільній освіти: Д. Баландіна, 
І. Тимофеєва (управління якістю освітнього процесу ДНЗ та оцінки управлінської діяльності його керівника), Т. Махиня (розвиток управлінських умінь керівників дошкільних навчальних закладів у системі підвищення кваліфікації), Р. Шаповал (формування управлінської компетентності керівника дошкільного навчального закладу), $А$. Пісоцька (соціально-педагогічні умови управління розвитком дошкільної освіти в регіоні), Л. Рибалко, Р. Черновол-Ткаченко, А. Яцинік (формування організаційної культури керівників дошкільних навчальних закладів у процесі магістерської підготовки та підвищення кваліфікаціі), А. Федорович (форми підготовки фахівців дошкільної освіти в Україні (початок XX ст.) та ін. Водночас накопичений теоретичний та емпіричний фактаж недостатньо сприятиме створенню умов під час підвищення кваліфікації керівників $3 Д О$ для формування їхньої професійної компетентності та, як наслідок, не забезпечує іï перебудову на суб'єктивну потребу фахівців та мету професійної діяльності на керівних посадах.

Мета статті - окреслити історико-педагогічні аспекти та визначити сучасні організаційно-метододогічні засади формування професійної компетентності керівників закладів дошкільної освіти під час післядипломного навчання.

Виклад основного матеріаду. Період активного розвитку вітчизняної дошкільної освіти як науки припадае на 60-70-ті pp. XX століття. Це час накопичення досвіду, осмислення теоретичного фактажу та емпіричних даних про ефективні методики навчання дітей та методи управління закладами освіти. Попри це, технологія нарощування управлінського потенціалу навчальних установ будувалася відповідно до партійних ідей та комуністичних принципів функціювання соціально-політичного устрою радянського суспільства та, як наслідок, набувала статусу тільки окремих наукових пошуків для емпіричних досліджень у країні. Сьогодні ми констатуємо посилення наукового інтересу до історико-педагогічних проблем розвитку дошкільної освіти, антропологічних засад та організаційних умов управління цим процесом, обгрунтування доцільності виокремлення й можливості імплементації в систему сучасного дошкільного менеджменту позитивних надбань з минулого століття. Адже «зміст дошкільної освіти, іiї взаємозв'язок з іншими ланками освіти можна зрозуміти в контексті історико-педагогічних та сучасних підходів» [10, с. 35].

Теоретичний аналіз архівних джерел $з$ розвитку дошкільної освіти в Україні у II половині XX століття та їі системоутворюючої основи - антропологічних засад, засвідчив значний впдив партійної ідеології на зміст підготовки керівних кадрів та морадьно-ціннісні складові управлінської культури директорів дитячих садків.

Нарощування кадрового й навчально-методичного потенціалу закладів дошкільної освіти в Україні у 60-х - 80-х рр. XX століття супроводжувалося проблемами професійної підготовки керівних кадрів для цієї ланки освіти в умовах вищої та післядипломної освіти. Формування їх професійної компетентності пов'язано із суспільною вимогою до підвищення якості управдіння педагогічним та допоміжним персоналом, а також освітнім процесом для забезпечення повноцінного розвитку дитини.

Попри це, перші установи для здобуття фаху дошкільної освіти та, відповідно, керівників дитячих садків з'явилися ще на початку XX століття. Назва одного 3 таких асоціювалося з прізвищем Ф. Фребеля та Фребелівського педагогічного товариства, яке займалося популяризацією ідей виховання дітей дошкільного віку та створенням народних дитячих садків. Так, у 1907 році Фребелівське педагогічне товариство заснувало в Києві Фребелівський педагогічний інститут як заклад вищої освіти, слухачі якого здобували кваліфікацію вихователя і керівника дитячого садка [8, с. 243-244]. Примітно, що зміст освіти у ньому охоплював різнорівневі ланки і включав підготовку фахівців на короткотермінових педагогічних курсах. Вони були непоодинокі і затребувані 
в країні, свідченням чого стало запровадження С. Русовою для консультування фахівців із дошкільної освіти у спеціальному науково-методичному центрі - дошкільному семінарії, а пізніші й відкриття українського відділення при Фребелівському інституті з курсами підготовки педагогічних та керівних кадрів для дошкільних установ [8, с. 245].

Розвитку їхньої професійної компетентності та формуванню управлінської культури сприяли курси підвищення кваліфікації педагогічних працівників та фахівців дошкільної освіти в 1920-х рр. (міжрайонні курси, Вищі трирічні курси та ін.). Вони заклади передумови формування професійної компетентності керівників ЗДО в сучасних установах підвищення кваліфікації.

У дослідженні ми відобразимо змістовну характеристику професійної компетентності керівника ЗДО та спробуємо схарактеризувати організаційнометодологічні засади технологіï iï формування в умовах сучасних установ післядипломної освіти.

Аналіз теоретичних засад проблеми дослідження дав змогу визначити професійну компетентність керівника закладу дошкільної освіти як інтеградьну характеристику сукупності його знань, умінь, навичок і досвіду, що визначають його здатність та гарантують готовність до професійного виконання керівних задач.

Сама дефініція «компетентність» у тлумаченні стандартних понять Базового компонента дошкільної освіти означає «динамічну комбінацію знань, умінь, навичок, способів мислення, поглядів, цінностей, інших особистісних якостей, що означає здатність особи успішно соціалізуватися, провадити професійну та/або подальшу навчальну діяльність» [3, с. 36].

У Професійному стандарті «Керівника закладу дошкільної освіти» стисло розкривається зміст його управлінської діяльності, яка «передбачає управлінську, організаційну та іншу діяльність у приміщенні, що використовується у освітньому процесі...» [4, с. 3].

Отже, ми частково ототожнюемо професійну компетентність керівника 3 його управдінською компетентністю, адже іiі зміст та сукупність змістових компонентів майже дотичні.

Так, наприклад, Р. Шаповал трактує управдінську компетентність керівника 3ДО «як інтегрованого особистісного утворення педагога, що відображає єдність його теоретичної та практичної готовності до ефективного здійснення різноманітних управлінських функцій (інформаційно-аналітичної, мотиваційно-цільової, плановопрогностичної, організаційної, контрольно-регулятивної та ін.)» [11, с. 1].

у своєму науковому досліджені вчений доводить, що «управлінська компетентність керівника ДНЗ передбачає: спрямованість на здійснення управлінської професійно-педагогічної діяльності (гуманістичний світогляд, настанови на пізнання й розуміння дюдини, підтримання процесів розвитку особистості вихователя і вихованця; особистісне прийняття цінностей педагогічного управління); сформованість мотивації вдосконалення педагогічної майстерності, сукупності особистіснопрофесійних якостей (енергійність, діловитість, здатність до роботи 3 июдьми, вимогливість до себе й інших дюдей, впливовість, толерантність, емпатія) та управлінських знань і вмінь, необхідних для практичного розв'язання завдань управління дошкільним навчальним закладом; розвиненість здатності до рефлексії й самоуправління» [там само, с. 9].

Таким чином, наявність професійної компетентності керівника є вимогою до здійснення професійної діядьності [4]. Їі наявність підтверджується відповідними документами на формальному рівні (дипломом про вищу освіту, атестаційним дистом, 
сертифікатом про проходження добровільної сертифікації педагогічних працівників та ін.), та прикладному (за наявністю сукупності відповідних складових), як, наприклад, управлінської культури.

Основою управлінської культури керівників закладів дошкільної освіти вважаємо управлінську компетентність, що являе собою готовність до здійснення управдінської діяльності на засадах суб'єкт-суб'єктної взаємодії.

Її невід'ємною складовою є якості, ділові та особистісні, що дозволяють приймати відповідні рішення та компетентно реалізовувати керівні функції посадовця. Тож з упевненістю можна сказати, що передумовами сформованості професійної компетентності є професійний розвиток керівника, що сприяє набуттю необхідних якостей, знань, досвіду і вмінь для успішної реалізації ним професійних обов'язків на керівній посаді.

Разом із проблемою управлінської культури до кола інтересів науковців (Л. Рибалко, Р. Черновол-Ткаченко, А. Яцинік) увійшла проблема організаційної культури керівників закладів дошкільної освіти, яку вони пропонують розв'язувати, у тому числі, у системі післядипломної освіти. У своєму дослідженні науковці розкривають особливості кожної: «управлінська культура звернена до чіткого виконання функціональних обов' язків, а організаційна - до його особистісно-професійних якостей, розвиток яких спрямовано на згуртування працівників навколо єдиної мети, отримання продуктивних результатів. Межу перетину цих культур становлять комунікативні й організаторські здібності, емпатія, рівень прагнень, самоконтродь, урівноваженість [7, с. 11].

Окремі аспекти проблеми професійного розвитку керівника в умовах післядипломної освіти розглянуто у працях А. Васильченко, Г. Закорченної, Т. Махині, М. Молочко, $\Lambda$. Пісоцької, $\Lambda$. Поздняк, Р. Шаповала, $\Lambda$. Шемятихиної та ін. Проте аналіз теоретичних засад проблеми професійного розвитку керівника закладу освіти констатує розбіжності у трактуванні поняття «професійний розвиток». Його розгдядають 3 позицій професійно-особистісного, професійно-компетентнісного розвитку та професійної діяльності безпосередньо. Так, з огляду на професійно-компетентнісний підхід у визначенні дефініції науковці (А. Данильєв, Б. Дьяченко, Г. Єльникова, О. Рудіна та ін.) характеризують професійний розвиток керівника закладу освіти як процес набуття ним нових компетенцій, знань, умінь і навиків, які він використовуе чи буде використовувати у своїй професійній діяльності; з позиції професійно-особистісного підходу - це об’єктивна потреба у сприянні особистісному розвитку керівників навчальних закладів, їх особистісних та професійних якостей як неодмінній умові їх професійного вдосконалення (Л. Даниленко, В. Семиченко та ін.); І. Зязюн, А. Жилина, С. Калашнікова, Т. Сорочан, І. Шпекторенко розглядають цей процес у контексті професійної діяльності і тлумачать його як процес професіоналізації особи, набуття нею професіоналізму та подальший його розвиток [1].

Отже, професійний розвиток має сприяти формуванню потреби фахівців щодо самовдосконалення та перетворення іï в мету професійної діяльності на керівних посадах.

Вимоги до професійної компетентності керівників ЗДО дещо ширші, аніж ті, що сприяють їхньому професійному зростанню. Вони включають досвід управління соціально-педагогічними системами, педагогічну майстерність, здатності оптимально реалізовувати управлінські функції, самостійно розв'язувати різноманітні завдання в нестандартних ситуаціях, ефективно взаємодіяти з учасниками педагогічного процесу, психологічну грамотність та впровадження педагогічних й організаційно-управлінських інновацій $[11$, с. 1]. Відсутність цілеспрямованої системи формування їхньої професійної 
компетентності в умовах післядипломної освіти зумовдюе необхідність визначення відповідних для цього організаційно-методичних умов.

За змістом управлінська діяльність керівника закладу дошкільної освіти є перетворювальною діяльністю, спрямованою на змінювання плану розвитку установи, методів управдіння педагогічним процесом та зміни особистості самого керівника у зв'язку з виконанням різноманітних функцій; за формою - це комунікативна діяльність, що включає безпосередне й опосередковане спілкування у процесі прийняття управлінського рішення; за структурою - ціннісно-орієнтаційна діяльність, спрямована на формування системи цінностей керівника та ії перенесення на учасників педагогічного процесу [11, с. 8].

Відповідно до Стандарту Керівника ЗДО його професійна компетентність складається із сукупності загальних, зокрема: громадянської (здатність діяти відповідно та свідомо, реалізовувати свої права й обов'язки як члена суспільств і громадянина держави та ін.), соціальної (здатність до ефективної комунікації і міжособистісної взаємодії, роботи в команді і т.д.), культурної (здатність до усвідомлення, цінування і поваги багатоманітності та мультикультурності у суспільстві), цифрової (здатність до впевненого та критичного використання цифрових технологій i ресурсів), підприємницької (здатність до генерування нових ідей, виявдення ініціативи та підприємдивості) та етичної компетентності (здатність усвідомдювати свої професійні можливості та діяти в межах рівня професійної підготовленості, доброчесності, соціальної відповідальності тощо [4].

Отже організаційно-методологічними засадами професійної підготовки керівників закладів дошкільної освіти вважаємо упровадження під час їхнього післядипломного навчання системи цілеспрямованого формування професійної компетентності, в основі якої лежить єдність компонентів: аксіологічно-мотиваційного (що об'єднуе ціннісні мотивації та мотиви управлінської діяльності), когнітивного (передбачає знання та накопичений досвід управлінської діяльності), діяльнісного (відображає вміння та навички керівника) та особистісного (є показником сформованості особистісних та професійних якостей керівника, що визначають характер виконання ним управлінських функцій).

Без сумнівів, для закладів дошкільної освіти сьогодні актуальною є потреба у керівних кадрах, які здатні проєктувати і здійснювати керівну діяльність на основі науково обгрунтованої оцінки якості й ефективності функціонування освітньої установи. Адже зміни, які ми зараз спостерігаємо у змісті дошкільної освіти через упровадження реформ та інновацій, вимагають компетентнісного підходу керівника до використання методів і форм управління людьми. Ядром професійної компетентності керівника закладу дошкільної освіти, на наш погляд, має бути кваліметрична складова, що відтворюе «єдність теоретико-управдінської підготовденості та практичної здатності комплексно застосовувати прикладні аналітико-оціночні технології у професійній сфері для вирішення варіативних завдань підвищення якості освіти» [9, с. 8]. Дана складова характеризуе метододогічну скдадову компетентності керівника 3 точки зору ефективної реалізації ним оцінки якості дошкільної освіти у своєму закладі.

У процесі формування професійної компетентності керівника закладу дошкільної освіти кваліметрична складова також відіграє неабияке значення. Моніторинг якості цього процесу впродовж курсів підвищення кваліфікації є фактором впливу на кінцевий результат. На думку Т. Махині, «розвинути управдінські вміння керівників закладів дошкільної освіти у системі підвищення кваліфікації стає можливо, якщо своєчасно здійснювати діагностику їх рівнів та забезпечити цілісність, системність і узгодженість цього процесу на основі принципів андрагогіки в курсовому періоді у відповідних 
закладах, у різноманітних формах методичної роботи з керівниками на рівні ЗДО, району і області у міжкурсовому періоді та під час здійснення ними самоосвітньої діяльності» [2, с.4]. Отже виділяємо в організаційні засади формування професійної компетентності керівників $3 Д О$ застосування комплексу діагностичних методик для моніторингу якості означеного процесу (моніторинг розвитку) впродовж професійного розвитку слухачів у системі післядипломної освіти.

Наступною складовою процесу формування професійної компетентності керівника 3ДО є мотиваційна, адже його кінцевим результатом є перетворення процесу професійного зростання на суб'єктивну потребу управлінця та мету його професійної діяльності.

На необхідності стимулювання розвитку позитивної мотивації набуття управлінської компетентності керівника закладу дошкільної освіти наголошуе Р. Шаповал. На його думку, «пізнання себе й усвідомлення своєї професійної діяльності, визначення освітніх потреб (виявлення конкретних знань, умінь, навичок, якостей, які необхідно опанувати), виявдення обсягу та характеру професійного й життєвого досвіду, з'ясування індивідуальних особливостей та визначення спектру мотивів педагогічної діяльності» є першим етапом в технології формування управлінської компетентності керівника ЗДО[11]. Зокрема, вчений виділяе три етапи означеного процесу: діагностично-проєктувальний, змістовно-процесуальний та оцінно-коригувальний, що передбачає самооцінювання та самокорекцію процесу особистісно-професійного вдосконалення керівника.

На мотиваційній складовій технології формування професійної компетентності керівників закладів дошкільної освіти в умовах системи підвищення кваліфікації акцентують й інші дослідники. А. Рибалко, Р. Черновол-Ткаченко, А. Яцинік наголошують, що «активізація мотиваційно-ціннісної сфери керівників ДНЗ (виявлення мотивів розвитку організаційної культури, інтересу до управлінської діяльності, прагнення покращувати способи педагогічної роботи 3 дітьми дошкільного віку, педагогічним колективом, батьками)» має бути саме першим етапом технології формування професійної компетентності керівників закладів дошкільної освіти в умовах системи післядипломної освіти» [7, с. 67].

На думку Т. Сорочан, провідною технологією розвитку професіоналізму управлінської діяльності керівників навчальних закладів у системі післядипломної педагогічної освіти є науково-методичний супровід. Його суб'єктами є керівники шкіл, науковці, методисти, працівники інституту пісдядипдомної педагогічної освіти, які спроможні забезпечити неформальну неперервність післядипломної освіти педагогічних і керівних кадрів [5].

Висновки. Таким чином, здійснене дослідження дозволяе зробити висновки про виокремлення 3 історії розвитку післядипломної освіти та сучасного стану iï функціонування дієвих організаційно-метододогічних засад професійної підготовки керівників закладів дошкільної освіти під час післядипломного навчання, забезпечення яких сприятиме, на наш погляд, формуванню їхньої професійної компетентності. Це такі, як-от: сприяння розвитку мотивації керівників до професійного вдосконалення та формування компетентності, що має бути їхньою особистісною потребою та метою професійної діяльності; визначення та дотримання під час курсів підвищення їхньої цільової спрямованості на компетентно-зорієнтований зміст; застосування комплексу діагностичних методик упродовж розвитку професійної компетентності слухачів (моніторинг розвитку) та організаційно-методологічне забезпечення програми курсів і профільних дисциплін у розрізі формування професійної компетентності керівника. 


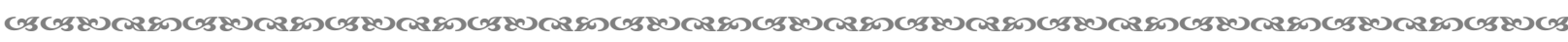
ПЕДАГОГІЧНИЙ АЛЬМАНАХ. - 2021. - ВИПУСК 50

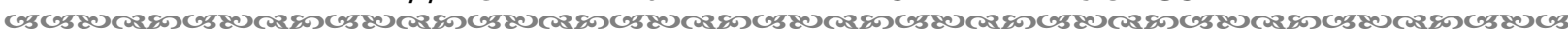

Перспективи подальшого наукового пошуку можуть бути пов'язані 3 дослідженням форм і методів навчання керівників закладів дошкільної освіти в умовах післядипломної освіти.

\section{Список використаних джерел:}

1. Бобир В.Г. Професійний розвиток керівника дошкільного навчального закладу. Науковий вісник уМО «Педагогіка» № 2 (2016) URL :http://umo.edu.ua/images/content/institutes/imp/vydannya/visnyk umo/pedagogika/2 2016 \%D0\%91\%D0\%BE\%D0\%B1\%D0\%B8\%D1\%80.pdf

2. Махиня Т.А. Розвиток управлінських умінь керівників дошкільних навчальних закладів у системі підвищення кваліфікації : автореф. дис. ... канд. пед. наук: 13.00.06. К., 2011. 20 с.

3. Наказ Міністерства освіти і науки України «Про затвердження Базового компонента дошкільної освіти (державного стандарту дошкільної освіти»» від 12.01.2021 р. № 33URL : https://mon.gov.ua/storage/app/media/rizne/2021/12.01/Pro novu redaktsiyu\%20Bazovoho\%20ko mponenta\%20doshkilnoyi\%20osvity.pdf

4. Наказ Міністерства освіти і науки України «Про затвердження професійного стандарту «Керівник (директор) закладу дошкільної освіти» від 28 вересня 2021 року № 620-21 URL : https://mon.gov.ua/ua/npa/pro-zatverdzhennya-profesijnogo-standartu-kerivnik-direktorzakladu-doshkilnoyi-osviti

5. Сорочан Т. М. Розвиток професіоналізму управдінської діяльності керівників загальноосвітніх навчальних закладів у системі післядипломної педагогічної освіти: автореф.дис ... д-ра пед.наук: 13.00.04. Ауганськ: Б.в., 2005. 43 с.

6. Семиченко В. А. Соціально-психологічні чинники мотивації професійного вдосконалення особистості керівних кадрів освіти: монографія. Київ, 2002. 135 с.

7. Рибалко А. С., Чорновол-Ткаченко Р. І., Яцинік А. В. Теоретичні питання розвитку організаційної культури керівників дошкільних навчальних закладів у системі післядипломної освіти : монографія. Харків : Вид. група «Основа», 2015. 112 с.

8. Федорович А. Форми підготовки фахівців дошкільної освіти в України (початок XXст.). Аюдинознавчі студіi. Серія «Педагогіка». Випуск 5/37 (2017). С. 240-251.

9. Фомина Н. Б. Формирование квалиметрической компетентности руководителя общеобразовательного учреждения в системе повышения квалификации: автореф. дис. ... канд. пед. наук: 13.00.08, 2010. Москва. 24 с.

10. Фунтікова О. О. Дошкільна освіта: історико-педагогічні та сучасні аспекти. Педагогіка формування особистості у вищій і загальноосвітній щколах. 2017. Вип. 56-57 (109-110). С. $28-37$.

11. Шаповал Р. В. Формування управлінської компетентності керівника дошкільного навчального закладу: автореф. дис. ... канд. пед. наук: 13.00.04. Х., 2009. 20 с.

\section{Reference:}

1. Bobyr, V. H. (2016). Profesiinyi rozvytok kerivnyka doshkilnoho navchalnoho zakladu [Professional development of the head of a preschool educational institution]. Naukovyi visnyk UMO «Pedahohika», 2. Retrieved from http://umo.edu.ua/images/content/institutes/imp/vydannya/ visnyk umo/pedagogika/2 2016/\%D0\%91\%D0\%BE\%D0\%B1\%D0\%B8\%D1\%80.pdf [in Ukrainian].

2. Makhynia, T. A. (2011). Rozvytok upravlinskykh umin kerivnykiv doshkilnykh navchalnykh zakladiv u systemi pidvyshchennia kvalifikatsii [Development of managerial skills of heads of preschool educational institutions in the system of advanced training]. (Extended abstract of Candidate's thesis). Kyiv [in Ukrainian].

3. On approval of the Basic component of preschool education (State Standard of preschool education), Order of the Ministry of Education and Science of Ukraine dated January 12, 2021 No.33. Retrieved from https://mon.gov.ua/storage/app/media/rizne/2021/12.01/Pro novu redaktsiyu\%20Bazovoho\%20komponenta\%20doshkilnoyi\%20osvity.pdf [in Ukrainian].

4. On approval of the Professional Standard "Head (director) of preschool institution", Order of the Ministry of Education and Science of Ukraine dated September 28, 2021 No. 620-21. Retrieved from 


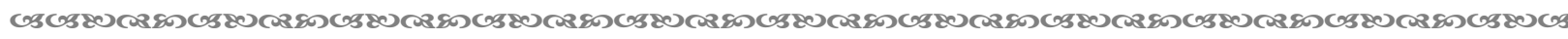
ПЕДАГОГІЧНИЙ АЛЬМАНАХ. - 2021. - ВИПУСК 50

U3

https://mon.gov.ua/ua/npa/pro-zatverdzhennya-profesijnogo-standartu-kerivnik-direktor-

zakladu-doshkilnoyi-osviti [in Ukrainian].

5. Sorochan, T. M. (2005). Rozvytok profesionalizmu upravlinskoi diialnosti kerivnykiv zahalnoosvitnikh navchalnykh zakladiv u systemi pisliadyplomnoi pedahohichnoi osvity [The development of management professionalism of general secondary school directors in the system of In-Service Teacher Training]. (Extended abstract of Doctor's thesis). Luhansk [in Ukrainian].

6. Semychenko, V. A. (2002). Sotsialno-psykholohichni chynnyky motyvatsii profesiinoho vdoskonalennia osobystosti kerivnykh kadriv osvity [Socio-psychological factors motivating the professional development of the personality of educational leaders]. Kyiv [in Ukrainian].

7. Rybalko, L. S., Chernovol-Tkachenko, R. I., \& Yatsynik, A. V. (2015). Teoretychni pytannia rozvytku orhanizatsiinoi kultury kerivnykiv doshkilnykh navchalnykh zakladiv u systemi pisliadyplomnoi osvity [Theoretical issues of development of organizational culture of heads of preschool educational institutions in the system of postgraduate education]. Kharkiv: Vyd. hrupa "Osnova» [in Ukrainian].

8. Fedorovych, A. (2017). Formy pidhotovky fakhivtsiv doshkilnoi osvity v Ukrainy (pochatok XX st.) [Forms of training of preschool education specialists in Ukraine (early twentieth century)]. Liudynoznavchi studii. Seriia «Pedahohika», 5/37, 240-251 [in Ukrainian].

9. Fomina, N. B. (2010). Formirovanie kvalimetricheskoi kompetentnosti rukovoditelia obshcheobrazovatelnogo uchrezhdeniia $v$ sisteme povysheniia kvalifikatcii [Formation of qualimetric competence of the head of a general education institution in the system of advanced training]. (Extended abstract of Candidate's thesis). Moskva [in Russian].

10. Funtikova, O. O. (2017). Doshkilna osvita: istoryko-pedahohichni ta suchasni aspekty [Preschool education: historical-pedagogical and modern aspects]. Pedahohika formuvannia osobystosti u vyshchii i zahalnoosvitnii shkolakh, 56-57 (109-110), 28-37 [in Ukrainian].

11. Shapoval, R. V. (2009). Formuvannia upravlinskoi kompetentnosti kerivnyka doshkilnoho navchalnoho zakladu [Formation of managerial competence of the head of the preschool educational institution]. (Extended abstract of Candidate's thesis). Kharkiv [in Ukrainian].

Sultanova N. V., orcid.org/0000-0003-3510-4662

\section{FORMATION OF PROFESSIONAL COMPETENCE OF A HEAD OF A PRESCHOOL EDUCATIONAL INSTITUTION IN THE POSTGRADUATE EDUCATION SYSTEM: HISTORY AND PRESENT}

Historical and pedagogical aspects, modern organizational and pedagogical principles of the process of forming professional competence of heads of preschool educational establishments in the conditions of postgraduate education institutions have been represented; the possibility of continuity of effective mechanisms and conditions has been substantiated.The influence of the party course on the training and functional responsibilities of heads in the preschool education system have been shown. Prerequisites for the development of educational institutions and courses for professional training of teachers and managers in Ukraine have been identified.

The urgency of forming professional competence of heads of preschool education institutions has been determined, which we interpret as a dynamic combination of knowledge, skills, abilities and other personal qualities that determine the ability and guarantee readiness for professional performance of managerial tasks.

The basics of managerial culture of managers and the content of managerial competence of directors of kindergartens have been revealed. The Professional Standard of a Head of a Preschool Education Institution has been analyzed and the requirements to its professional activity in the context of managerial responsibilities and functions have been singled out. It is emphasized that the development of professional competence of heads of preschool education institutions is facilitated by the development of their organizational culture, including in the system of postgraduate education. The methodological basis of professional development of heads of preschool educational 
institutions from the standpoint of professional-personal, professional-competence formation and professional activity has been outlined.

The essence of organizational and methodological principles of their professional training has been revealed, which is based on the unity of such components as axiological-motivational, cognitive and personal. It is emphasized that the core of professional competence of a head of a preschool educational institution is a qualimetric component that reproduces the unity of specialists' theoretical and managerial training and practical ability to comprehensively use applied analytical and evaluation technologies.

The motivational component, scientific and methodological support of advanced training courses as system-forming components of acquiring professional competence of a head of a preschool institution have been characterized. It is concluded that the observance of certain organizational and methodological principles of professional training of heads of preschool educational institutions in the conditions of postgraduate education will contribute to the most effective formation of their professional competence.

Key words: preschool education, History of Pedagogy, preschool educational institutions, head of a preschool educational institution, professional competence, managerial culture, organizational and methodological principles.

Дата надходженнястатті: 09.102021 p.

Рецензент: доктор педагогічних наук, професор Атаманчук Ю. М.

УДК 37.091.4(438)Оконь:37.0(477)

DOI https://doi.org/10.37915/pa.vi50.327

Терещук Г. В.*, orcid.org/0000-0003-1717-961X

Янкович О. I.*,

orcid.org/0000-0003-4253-5954

\section{ОСВІТНЯ, НАУКОВА Й УПРАВ АІНСЬКА ДІЯЯЬНІСТЬ ВІНЦЕНТА ОКОНЯ: ІСТОРІЯ ТА СУЧАСНИЙ КОНТЕКСТ}

У статті відображено життевий шлях, освітню, наукову й управлінську діяльність Вінцента Оконя - знаного у світі польського вченого, професора Варшавського університету, члена Польської академї̈ наук, засновника Польського педагогічного товариства, редактора польських педагогічних журналів, почесного члена Польського товариства дослідження ігор.

Зазначено вагомий внесок польського педагога в розвиток дидактики, педагогіки вищої школи, педевтології (науки про вчителя), історії педагогіки, порівняльної педагогіки. В. Оконь обьрунтував засади проблемного навчання, багатостороннвого навчання; розробляв проблеми психології й педагогіки гри та забави; довів необхідність розвитку активності учня в набутті знань, готовність до навчання впродовж життя, щз сьогодні трактуеться як ключова компетентність. Переконання вченого про партнерські стосунки вчителів, батьків і учнів закладено у формулу Концепціӥ Нової української школи.

Визначено перспективи використання ідей В. Оконя в сучасній освітній галузі Украйни та Польщі: підвищення ефективності проблемного навчання за умови реалізації з груповими формами роботи; єдність процесів набуття знань, виховання изінностей, волі, переконань учнів; формування самостійності та відповідальності особистості як шлях до зміни світу;

${ }^{*}(\mathrm{C}$ Терещукк.В.

"(C) Янкович O.I.

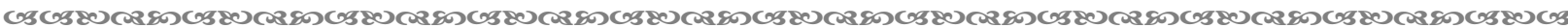
226 